\title{
Structure and Biochemical Analysis of Phytoplankton in the Wadi El-Rayan Lakes, El-Fayoum, Egypt.
}

\author{
Soaad A. Sabae and Abeer M.A. Mahmoud
}

National Institute of Oceanography and Fisheries (NIOF), Cairo, Egypt.

* Correspondence: E-mail:

Tel.: +2 013 2460640; Fax: +2 0132463074 .

Received: March 22, 2021; Accepted: April 24, 2021 published: 2021 Vol.11 (2):17-32

\section{ABSTRACT}

Wadi El-Rayan lakes are an important source of irrigation water and fisheries in El-Fayoum Governorate, Egypt. Phytoplankton is an important bioindicator of the physicochemical and biological changes in natural ecosystems including the Wadi El-Rayan lakes. Seasonal and regional variations lead to concomitant changes in the total protein, carbohydrate, and lipid contents of phytoplankton; such changes affect the nutritional quality of food available in the aquatic system. In the present study, these changes were determined in the phytoplankton of Wadi El-Rayan lakes. The maximum protein (27.95 \& $11.36 \mathrm{mgL}^{-1}$ ) contents were detected during summer and winter respectively. The maximum carbohydrate content was detected in autumn and winter (1.76 and $1.12 \mathrm{mgL}^{-1}$ at site 8 and 4 respectively). The maximum lipid content was observed in winter $\left(0.73 \mathrm{mgL}^{-1}\right.$ at site 6). Phytoplankton density was much higher in the upper lake than in the lower lake. In total, 92 species were identified; the phytoplankton community in the two lakes included typical groups such as Chlorophyceae, Cyanophyceae, Bacillariophyceae, Cryptophyceae, Dinophyceae, Chrysophyceae, and Euglenophyceae. The green alga was the dominant group, constituting 44.4\%-45.0\% of the phytoplankton standing crop across seasons. Cyanophyceae $(29 \%-39 \%)$, Bacillariophyceae $(9.7 \%-16.1 \%)$, and Dinophyceae (4.0\%-9.2\%) were the next most abundant classes; Cryptophyceae, Chrysophyceae, and Euglenophyceae were rarely found. The major peak of phytoplankton density $\left(7684 \times 10^{4} \mathrm{Cells} \mathrm{L}^{-1}\right)$ was observed during winter, whereas the minor peak was detected during summer $\left(4879 \times 10^{4}\right.$ Cells $\left.\mathrm{L}^{-1}\right)$. Cosmarium nitidulum (Brebisson) Ralfs, Dictyosphaerium pulchellum Wood, Oocystis solitaria Wittrock, Gomphosphaeria compacta (Lammermann) Ström, Lyngbya 
limnetica Lemmermann, Microcystis aeruginosa Kützing, Cyclotella meneghiniana Kutz., and Syndra ulna (Nitzsch) Ehr. were the most abundant species identified. More detailed studies on the biochemical structure of phytoplankton are needed to better understand Wadi ElRayan lakes' response to the many environmental changes.

Keywords: Wadi El-Rayan Lakes; phytoplankton; biochemical analysis.

\section{INTRODUCTION}

The Wadi El-Rayan lakes are a natural protected area and important source of irrigation water and fisheries in El-Fayoum Governorate, Egypt. Wadi El-Rayan depression (Southwest of Cairo in the Western desert of Egypt) holds two man-made lakes that receive the wastewater drainage of El-Fayoum depression. Phytoplankton plays an important role in the equilibrium of many aquatic ecosystems. The biochemical content of phytoplankton is an important indicator of their nutritional quality (Müller-Navarra et al., 2000). Seasonal and regional variations lead to changes in the total protein, carbohydrate, and lipid contents of phytoplankton; these changes affect the nutritional quality of food available in the aquatic system (Boëchat and Giani, 2008). The water quality of a water body depends on many physical, chemical, and biological indicators (Poonam et al., 2013). The health of all living organisms in an aquatic ecosystem is affected by the quality of water (Doherty et al., 2010). Specifically, Saeed and Ibrahim (2008) reported that inorganic and organic chemical pollution of the aquatic environment poses a serious threat to the survival of aquatic organisms. In addition, several industrial and agricultural processes cause environmental pollution and contribute to the contamination of water ecosystems (Mohamed $\boldsymbol{e t}$ al., 2017). Wadi El-Rayan lakes receive agricultural wastewater drainage from the El-Wadi Drain and vary in their physical and chemical characteristics (Ali et al., 2007). According to the evaporation of water from the Wadi El-Rayan lakes, the gradual increase in concentrations of salts, heavy metals, pesticides, and other pollutants is changing their water quality and likely affecting aquatic life (Mansour and Sidky, 2003; Paleczny et al., 2007). Thus, the physicochemical and biological properties of the Wadi El-Rayan lakes have been extensively studied (Abd ElKarim, 2004; Abdel Hameed et al., 2007; Ali et al., 2007; Abdel-Satar and Goher, 2015). In terms of phytoplankton, the upper lake has a more condensed population than the lower one, while maximum and minimum phytoplankton production has been recorded in winter and spring, respectively (Taha and Farghaly, 1994). To build on these previous studies, the current phytoplankton 
community structure of the Wadi El-Rayan lakes and its biochemical content across seasons were analyzed.

\section{MATERIALS AND METHODS}

\section{Study area:}

Wadi El-Rayan holds two main lakes at different elevations that are connected by a swampy channel. They lie between $30^{\circ} 20^{\prime}-30^{\circ} 25^{\prime} \mathrm{E}$ and $29^{\circ} 05^{\prime}-29^{\circ} 20^{\prime} \mathrm{N}$ (Fig. 1).

\section{Samples locations:}

Ten stations were chosen to cover the area under investigation. Stations 1-5 and stations 6-10 represent the upper and lower lakes, respectively; and the El-Wadi Drain station (Fig. 1). This study was seasonally conducted from autumn 2019 to summer 2020.

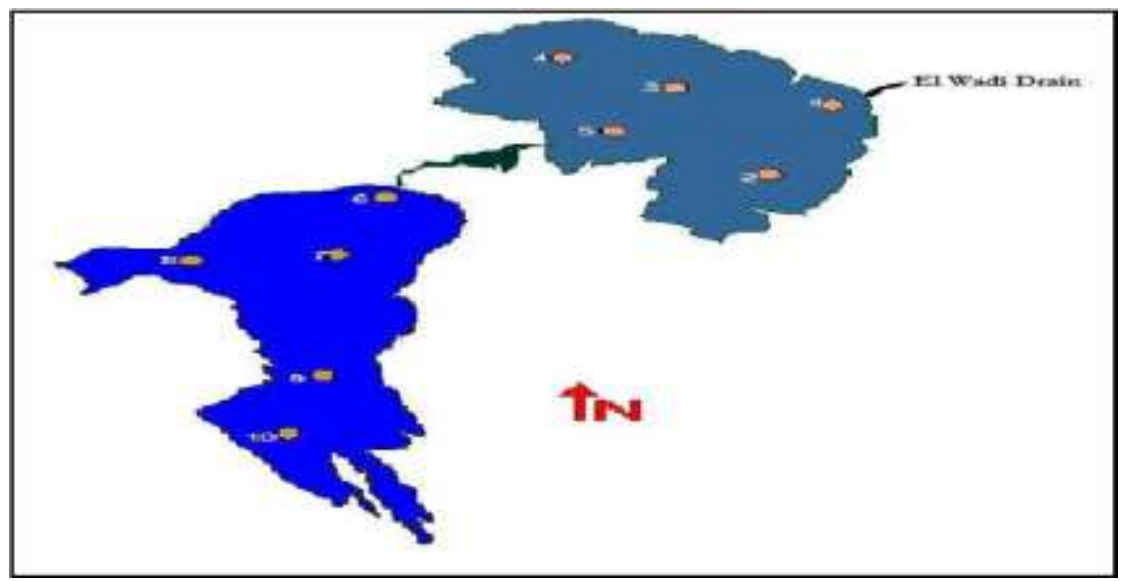

Fig. 1: Map of Wadi El-Rayan lakes showing the samples' locations.

\section{Qualitative estimation of phytoplankton:}

Water samples were collected from the sites described previously; phytoplankton in the sample was concentrated by settling $500 \mathrm{ml}$ water sample in a volumetric cylinder for about 5days after being preserved with Lugol's solution ( $10 \mathrm{~g}$ of pure iodine, $20 \mathrm{~g}$ of potassium iodide KI, $200 \mathrm{~mL}$ of distilled water, and $20 \mathrm{ml}$ of glacial acetic acid). This solution facilitates the sedimentation and staining of phytoplankton cells. During time phytoplankton organisms were allowed to settle by gravitation (APHA, 1992). The supernatant was then carefully siphoned off with a small plastic tube including a fine net $(20 \mu \mathrm{m}$ mesh diameter) until the samples were concentrated to about $50 \mathrm{~mL}$. The remaining volume was adjusted to exactly $50 \mathrm{~mL}$, and the samples were kept at $4^{\circ} \mathrm{C}$ in a dark plastic vial until microscopic examination. Phytoplankton counts were conducted using a wild inverted microscope (Zeiss 
Axiovert 25C); $5 \mu \mathrm{L}$ of the reduced-volume sample was placed in a counting chamber and examined with a $10 \times$ eyepiece and $40 \times$ objective. The drop method (APHA, 1992) was applied for both the counting and identification of different algal species from different samples. Algal taxa were identified according to standard references including Kofoid (1911), Kofoid and Swez (1921), Lebour and Marie (1930), Hannford and Britton (1952), Henedy (1964), Bourrely (1968), Prescott (1978), Mizuno (1990), and Krammer and Lang Bertalot (1991).

\section{Biochemical analysis:}

The total protein content was determined using the biuret method (David and Hazel, 1993). The hydrolysis of carbohydrates was conducted using the method of Myklestad and Haug (1972), and the carbohydrate content was determined according to the work of Dubois $\boldsymbol{e t}$ al., (1956). The total lipid content was determined according to the method of Chabrol and Castellano (1961).

\section{Statistical analysis:}

Relation between phytoplankton and the three biochemical parameters (proteins, lipids, and carbohydrates) was calculated by principal component analysis (PCA), using XLSTAT (2021) program.

\section{RESULTS AND DISCUSSION:}

There was a large variation in the biochemical content of phytoplankton among species and locations across the seasons. Generally, total protein was the major biochemical constituent of the phytoplankton community; the protein content of algae is also an important criterion for their use as food (Fawzy et al., 2017). In contrast, the total lipid content was the minor constituent of the biochemical composition of the communities. As shown in Fig. 2, the maximum protein $\left(27.95 \& 11.36 \mathrm{mgL}^{-1}\right)$ contents were detected in summer and winter respectively. Proteins are important components of all membranes, involved in the transport of other molecules and ions across the membranes. Most enzymes are proteins that organize, construct and receive signals, while the structural proteins maintain the shape of the cell (Jónasdóttir 2019). The maximum carbohydrate content was detected in autumn and winter (1.76 and $1.12 \mathrm{mgL}^{-1}$ at sites 8 and 4 respectively). The maximum lipid content was observed in winter $\left(0.73 \mathrm{mgL}^{-1}\right.$ at site 6$)$. The biochemical content of phytoplankton cannot explain the variation observed in the consumer's growth when fed different phytoplankton types. So, it is necessary to look further into the more detailed structure of the classes. 


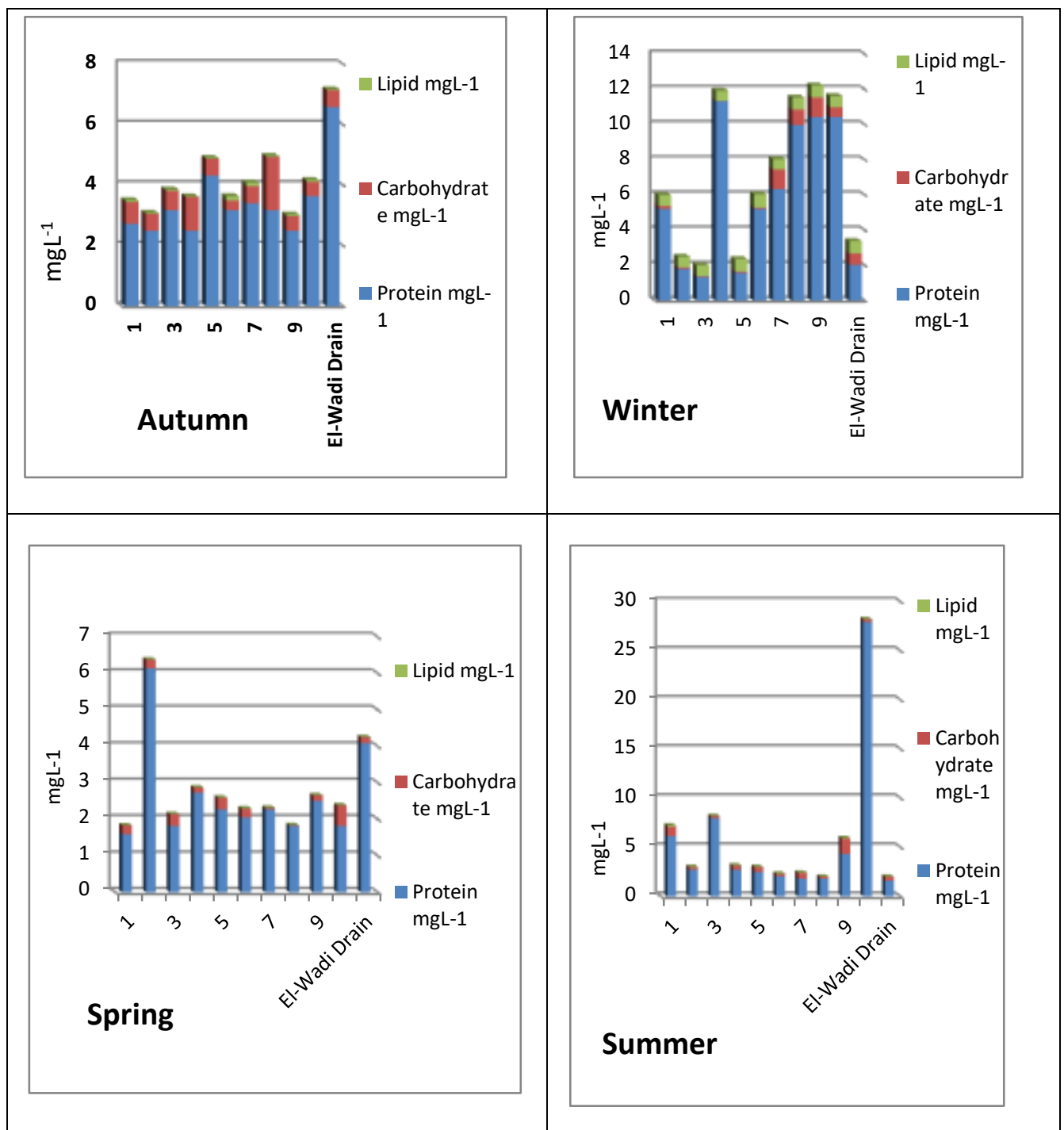

Fig. 2: The biochemical content of phytoplankton in Wadi El-Rayan lakes across the seasons (from autumn 2019 to summer 2020). 


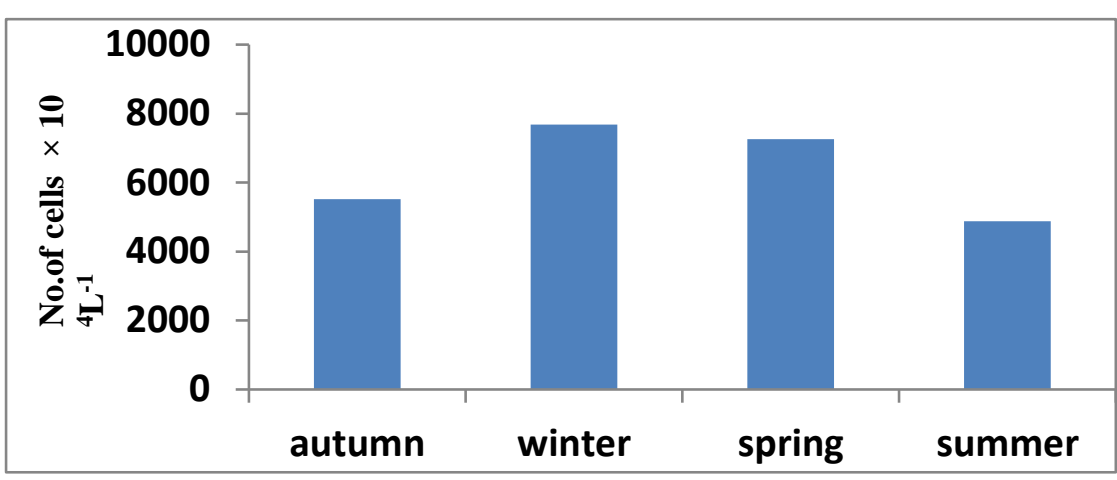

Fig. 3: Seasonal variation in total phytoplankton density $\left(\times 10^{4}\right.$ Cells $\left.\mathrm{L}^{-1}\right)$ in Wadi El-Rayan lakes (from autumn 2019 to summer 2020).

The seasonal distribution of phytoplankton showed two major peaks in density: 7684 and $7260 \times 10^{4}$ Cells $\mathrm{L}^{-1}$ in winter and spring, respectively. The lowest peak in density was detected in summer $\left(4879 \times 10^{4} \mathrm{Cells} \mathrm{L}^{-1}\right)$. In the present study, phytoplankton density was much higher in the upper lake than in the lower lake (Table 1); this was likely due to the high nutrient concentrations received by the upper lake from drainage water via the El-Wadi Drain, which is again similar to that reported by Konsowa (2007).

In total, 92 species were identified in the present study (Table 2). The phytoplankton community in the lake was composed of typical groups (Fig. 4 and Table 1), e.g., Chlorophyceae, Cyanophyceae, Bacillariophyceae, Cryptophyceae, Dinophyceae, Chrysophyceae, and Euglenophyceae. The green alga was the most dominant class $(44.4 \%-45.0 \%$ of the phytoplankton standing crop across seasons), followed by Cyanophyceae (29\%-39\%), Bacillariophyceae (9.7\%-16.1\%), and Dinophyceae (4.0\%-9.2\%). In contrast, Cryptophyceae, Chrysophyceae, and Euglenophyceae were rarely found.

Chlorophyceae (green algae) was the dominant phytoplankton group, with 34 Chlorophyceae taxa identified. The most common green algal taxa were Cosmarium nitidulum (Brebisson) Ralfs, Oocystis borgei Snow, Dictyosphaerium pulchellum Wood, Planktonema lauterbornii Schmidle, and Oocystis solitaria Wittrock (Fig.5). The presence of Tetraedron minimum (A.Braun) Hansgirg and Scenedesmus spp. in the lake water indicated that it was a eutrophic environment (El-Sheekh et al., 2018).

Cyanophyceae (Blue-green algae) including 17 taxa, was the second major constituent group in the study area; the dominant species were Gomphosphaeria compacta (Lammermann) Ström, Lyngbya limnetica Lemmermann, and Microcystis aeruginosa Kützing. These species can tolerate a wide range of salinity and fluctuations in Wadi El-Rayan water chemistry. These findings are in agreement with those of Konsowa and Taha (2002). In 
addition, Konsowa and Abd Ellah (2002) observed M. aeruginosa in the first lake during winter and L. limnetica in the second lake during summer.

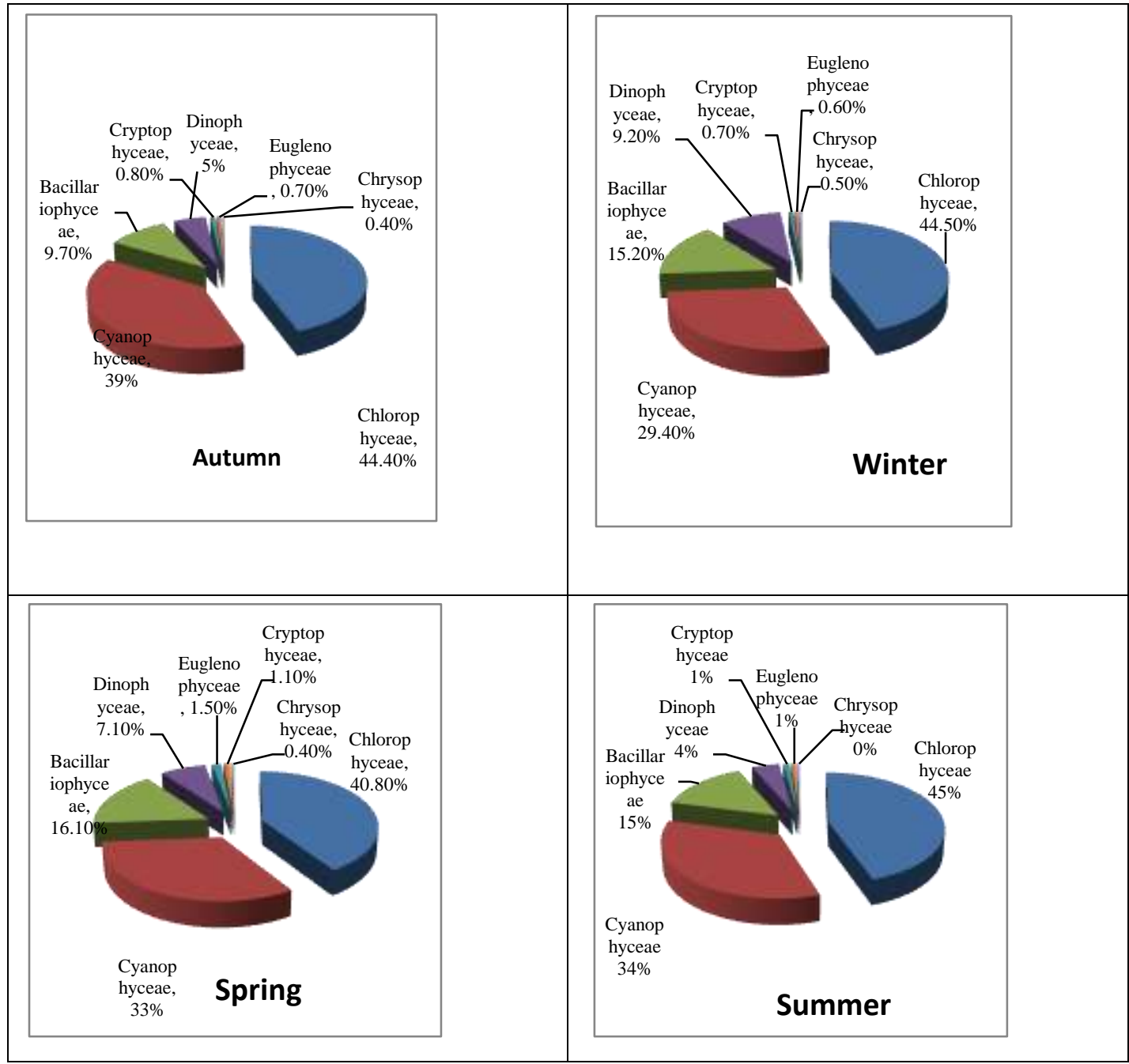

Fig. 4: Phytoplankton community composition across the seasons (from autumn 2019 to summer 2020) in the Wadi El-Rayan lakes.

Bacillariophyceae (Diatoms) was the third most predominant algae after green and blue-green (Fig. 4). In total, 28 taxa related to Bacillariophyta were identified (Table 2). The most abundant species of diatoms were Cyclotella meneghiniana Kutz., Nitzschia paleacea Grum, and Syndra ulna (Nitzsch) Ehr. Four phytoplankton classes, Chrysophyceae, Cryptophyceae, Dinophyceae, and Euglenophyceae, were rarely found; thus, their standing 
crops were low (Table 2). These classes are related to the increase in water salinity in the lower lake (Konsowa, 2005). Abd Ellah (2016) stated that the lower lake has faced extreme water loss over the last 20 years due to the extension of agricultural land and fish farms in the depression.

Table 1: Spatial and seasonal variations in the class composition of phytoplankton Count $\left(\times 10^{4} \mathrm{Cells}^{-1}\right)$ in Wadi El-Rayan lakes and their drain.

\begin{tabular}{|c|c|c|c|c|c|c|c|c|c|c|c|c|c|}
\hline Site & 1 & 2 & 3 & 4 & 5 & 6 & 7 & 8 & 9 & 10 & Drain & Total & Average \\
\hline \multicolumn{14}{|c|}{ Autumn } \\
\hline Chlorophyceae & 409 & 540 & 390 & 484 & 229 & 40 & 89 & 91 & 74 & 65 & 44 & 2455 & 223.2 \\
\hline Bacillariophyceae & 98 & 10 & 110 & 80 & 76 & 2 & 34 & 38 & 20 & 20 & 50 & 538 & 48.9 \\
\hline Cyanophyceae & 492 & 398 & 417 & 281 & 113 & 87 & 151 & 82 & 29 & 8.7 & 90 & 2148 & 195.3 \\
\hline Dinophyceae & 20 & 130 & 21 & 24 & 10 & 35 & 4 & 13 & 11 & 10 & 0 & 278 & 25.3 \\
\hline Cryptophyceae & 8 & 10 & 4 & 4 & 5 & 4 & 2 & 4 & 2 & 0 & 0 & 43 & 3.9 \\
\hline Euglenophyceae & 7 & 0 & 4 & 2 & 8 & 10 & 2 & 2 & 4 & 0 & 0 & 39 & 3.5 \\
\hline Chrysophyceae & 2 & 0 & 6 & 0 & 10 & 0 & 1 & 0 & 4 & 0 & 0 & 23 & 2.1 \\
\hline $\begin{array}{l}\text { Total } \\
\text { phytoplankton }\end{array}$ & 1036 & 1088 & 952 & 875 & 451 & 178 & 283 & 230 & 144 & 104 & 184 & 5524 & 502.2 \\
\hline \multicolumn{14}{|c|}{ Winter } \\
\hline Chlorophyceae & 526 & 502 & 546 & 453 & 220 & 80 & 257 & 141 & 49 & 54 & 590 & 3418 & 310.7 \\
\hline Bacillariophyceae & 66 & 85 & 98 & 76 & 106 & 96 & 43 & 50 & 20 & 18 & 508 & 1166 & 106.0 \\
\hline Cyanophyceae & 196 & 454 & 468 & 221 & 120 & 77 & 256 & 152 & 66 & 70 & 182 & 2262 & 205.6 \\
\hline Dinophyceae & 6 & 40 & 47 & 16 & 80 & 110 & 17 & 14 & 20 & 14 & 340 & 704 & 64.0 \\
\hline Cryptophyceae & 2 & 0 & 2 & 8 & 20 & 10 & 2 & 4 & 2 & 0 & 0 & 50 & 4.5 \\
\hline Euglenophyceae & 3 & 0 & 2 & 3 & 10 & 0 & 4 & 1 & 2 & 2 & 22 & 49 & 4.5 \\
\hline Chrysophyceae & 0 & 0 & 6 & 0 & 10 & 10 & 2 & 0 & 5 & 2 & 0 & 35 & 3.2 \\
\hline $\begin{array}{l}\text { Total } \\
\text { phytoplankton }\end{array}$ & 799 & 1081 & 1169 & 777 & 566 & 383 & 581 & 362 & 164 & 160 & 1642 & 7684 & 698.5 \\
\hline
\end{tabular}


Con. Table 1:

\begin{tabular}{|c|c|c|c|c|c|c|c|c|c|c|c|c|c|}
\hline Site & 1 & 2 & 3 & 4 & 5 & 6 & 7 & 8 & 9 & 10 & Drain & Total & Average \\
\hline \multicolumn{14}{|c|}{ Spring } \\
\hline Chlorophyceae & 746 & 482 & 415 & 346 & 201 & 161 & 212 & 113 & 123 & 89 & 76 & 2964 & 269.5 \\
\hline Bacillariophyceae & 294 & 188 & 118 & 132 & 58 & 68 & 60 & 64 & 56 & 72 & 60 & 1170 & 106.4 \\
\hline Cyanophyceae & 620 & 260 & 390 & 297 & 164 & 184 & 188 & 85.7 & 96.9 & 35.4 & 75.4 & 2395 & 217.8 \\
\hline Dinophyceae & 126 & 62 & 65 & 64 & 43 & 38 & 24 & 36 & 30 & 16 & 10 & 514 & 46.7 \\
\hline Euglenophyceae & 26 & 12 & 14 & 16 & 6 & 4 & 8 & 16 & 10 & 0 & 0 & 112 & 10.2 \\
\hline Cryptophyceae & 21 & 14 & 12 & 2 & 6 & 6 & 4 & 4 & 8 & 0 & 0 & 77 & 7.0 \\
\hline Chrysophyceae & 10 & 10 & 4 & 0 & 4 & 0 & 0 & 0 & 0 & 0 & 0 & 28 & 2.5 \\
\hline $\begin{array}{l}\text { Total } \\
\text { phytoplankton }\end{array}$ & 1843 & 1028 & 1018 & 857 & 482 & 461 & 496 & 319 & 324 & 212 & 221 & 7260 & 660.0 \\
\hline \multicolumn{14}{|c|}{ Summer } \\
\hline Chlorophyceae & 590 & 396 & 337 & 319 & 160 & 32 & 88 & 82 & 66 & 90 & 32 & 2192 & 199.3 \\
\hline Bacillariophyceae & 158 & 28 & 121 & 74 & 58 & 20 & 48 & 50 & 40 & 44 & 66 & 707 & 64.3 \\
\hline Cyanophyceae & 377 & 275 & 306 & 197 & 94.9 & 87 & 141 & 53.5 & 30 & 21.1 & 93.1 & 1676 & 152.3 \\
\hline Dinophyceae & 56 & 30 & 22 & 22 & 24 & 17 & 12 & 9 & 7 & 5 & 5 & 209 & 19.0 \\
\hline Cryptophyceae & 13 & 6 & 2 & 6 & 4 & 0 & 4 & 2 & 2 & 0 & 0 & 39 & 3.5 \\
\hline Euglenophyceae & 8 & 4 & 8 & 2 & 0 & 2 & 0 & 10 & 4 & 0 & 0 & 38 & 3.5 \\
\hline Chrysophyceae & 4 & 2 & 6 & 0 & 0 & 0 & 6 & 0 & 0 & 0 & 0 & 18 & 1.6 \\
\hline $\begin{array}{l}\text { Total } \\
\text { phytoplankton }\end{array}$ & 1206 & 741 & 802 & 620 & 341 & 158 & 299 & 207 & 149 & 160 & 196 & 4879 & 443.5 \\
\hline
\end{tabular}




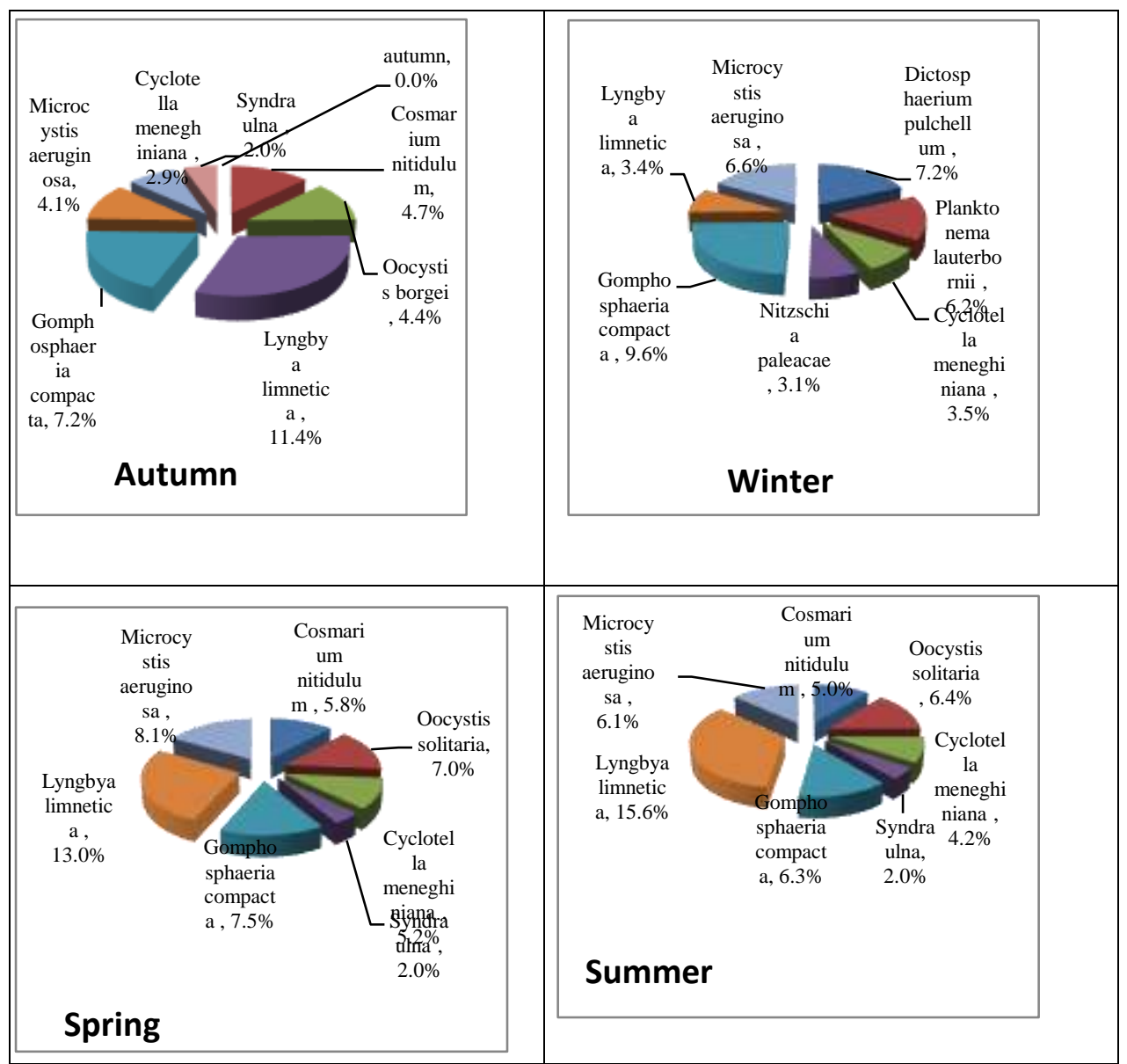

Fig. 5: Percentage abundance of the most common species of phytoplankton in Wadi El-Rayan lakes.

As shown in Fig. 6, the principal component analysis indicated that total phytoplankton was directly related to Chlorophyceae, Cyanophyceae, and L. limnetica, while Bacillariophyceae had high lipid levels relative to protein and carbohydrate levels. Overall, these results suggest that the biochemical content of phytoplankton can be a good indicator of their nutritional value. 


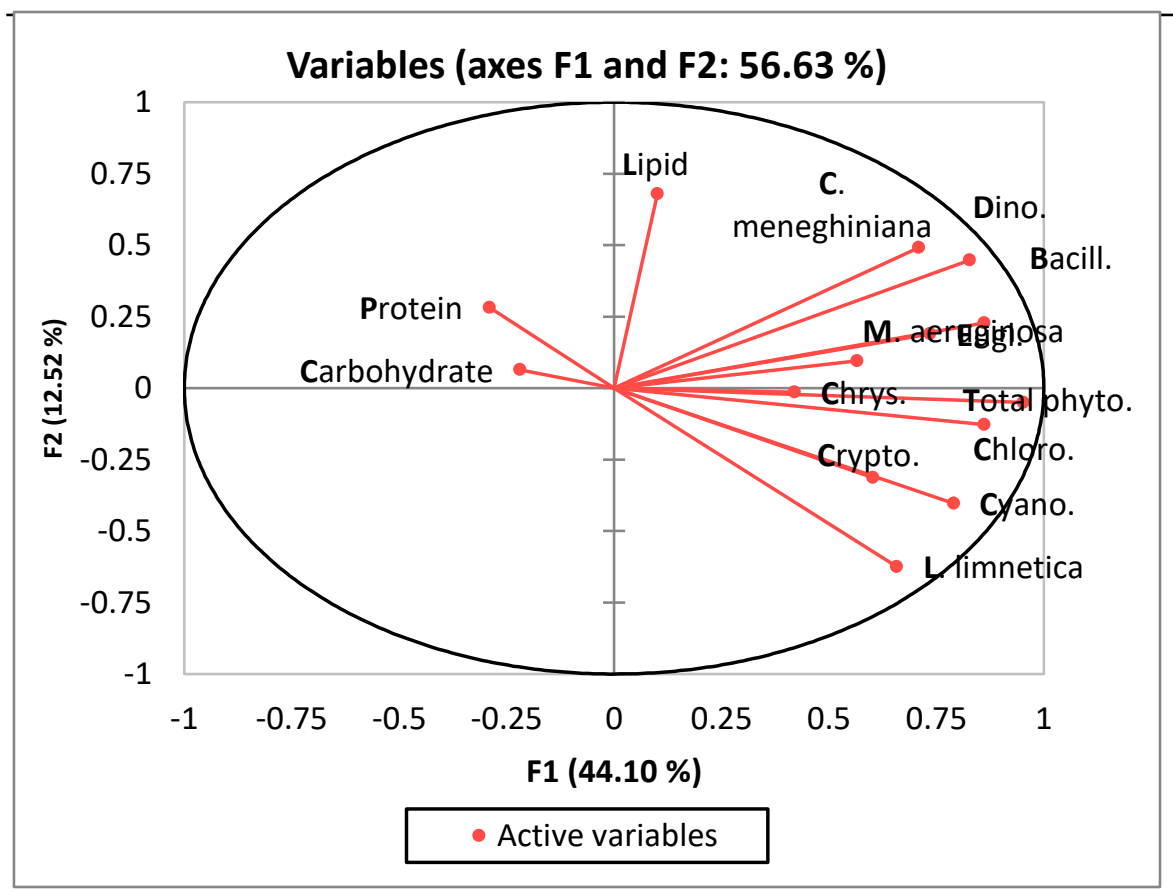

Fig. 6: Principal component analysis of biochemical and biological variables measured at the various stations of Wadi El-Rayan lakes and drain. Chloro, Chlorophyceae; Bacill, Bacillariophyceae; Cyano, Cyanophyceae;Cryp, Cryptophyceae; Chrys, Chrysophyceae; Eugl, Euglenophyceae; Dino, Dinophyceae; Total Phyto, Total phytoplankton; M. aeruginosa, Microcystis aeruginosa; L. limnetica, Lyngbya limnetica; C. meneghiniana, Cyclotella meneghiniana.

Table 2: List of phytoplankton species in the Wadi El-Rayan lakes and drain.

\section{Chlorophyceae}

Actinastrum hantzschii var. fluviatile J.B.L.Schröder

Ankistrodesmus falcatus (Corda) Ralfs

Ankistrodesmus falcatus v. acicularis (Braun.) West

Ankistrodesmus fusiformis Corda

Chlamydomonas globosa Snow

Cosmarium amgulosum Brebisson

Cosmarium depressum

Cosmarium nitidulum (Brebisson) Ralfs.

Dictosphaerium pulchellum Wood

Elakatothrix gelatinosa Wille

Gonium sociale (Dujardin) Warming

Keratococcus suecicus Hindák

Kirchneriella contorta (Schmidle) Bohlin Kirchneriella contorta var. elegans (PLAYFAIR) KOMÁREK

Kirchneriella irregularis (Petyk.) Printz

Legerheimia ciliata. (Lag.) Chodat. L.
Nephrocytium subsolitaria

Oocystis borgei Snow

Oocystis elliptica W. West

Oocystis gigas var. minor West \& G.S.West.

Oocystis parva W.\&G.S. West

Oocystis solitaria Wittrock

Planktonema lauterbornii Schmidle

Scenedesmus bicudatus Dedusenko

Scenedesmus dimorphus ( Turpin ) Küzing

Scenedesmus ecornis ( Ehrenberg ) Chodat

Scenedesmus opoliensis P.G.Richter

Scenedesmus quadricauda ( Turpin ) Brébisson

Scenedesmus quadricauda v. quadrispina

(Chod.) Smith

\section{Staurastrum chaetoceras}

Staurastrum paradoxum Meyen ex Ralfs

Tetraëdron minimum (A.Braun) Hansgirg 
Monoraphidium contortum (Thuret) KomárkováLegnerová

\section{Con. Table 2:}

\section{Bacillariophyceae}

Amphora coffeaeformis Kutz.

Bacillaria paradoxa Gemelin

Chaetoceros curvesetus Cleve

Cocconies placentula Ehr.

Cosinodiscus divisis Grun.

Cyclotella bodanica Eulenstein ex Grunow

Cyclotella glomerata Bachmann

C. kutzingiana Thwait.

Cyclotella ocellata Pant

Cyclotella operculata (Ag.) kutz.

Cyclotella meneghiniana kutz.

C. stelligera Cleve \& Grun.

Cymbella microcephala Grunow in Van Heurck

Epithemia proboscidea Kützing
Fragillaria capucina Desm

Gomphonema parvulum var. longenula Ktz.

Navicula confervacea (Kützing) Grunow

Navicula cryptocephala Kützing

Navicula festiva Krasske

Nitzschia closterium (Ehrenberg) W.Smith

Nitzschia filiformis (W.Smith) Van Heurck

Nitzschia frustulum (Kützing) Grunow

$N$. gracilis Hantz

N. palea (Kutz.) W. Smith

N. tryblionellae Hant

Stephanodiscus astraea (Ewhren.) Grun

Synedra tabulata var. acuminata (Grun) Hust.

Syndra ulna (Nitzsch) Ehr.

\section{Cyanophyceae}

Chroococcus minutus (Kützing) Nägeli

Cylindrospermopsis raciboroskii Woloszynska Gomphosphaeria compacta (Lammermann) Ström

Gomphosphaeria fusca Skuja Limnococcus limneticus (Lemmermann) Komárková

Lyngbya limnetica Lemmermann

Lyngbya profundalis Lindstedt

Merismopedia elegans A.Braun ex Kützing

Microcystis aeruginosa Kützing

\section{Cryptophyceae}

Cryptomonas obovata

Ehrenberg

Cryptomonas phaseolus Skuja Chroomonas salina (Wills.)

Butch

\section{Dinophyceae}

Gymnodinium biconica Skuja

Peridinium bipes Stein

Peridinium penardii (Lemm.) Lemm.

Prorocentrum micans Ehr
Microcystis flosaquae (Wittrock) Kirchner

Microcystis grevillei (Hassall) Elenkin

Oscillatoria brevis (Kutz.) Gom.

Phormidium interruptum Kutz

phormedium frigidum Fritsch

Phormidium laminosum Gomont ex Gomont Pseudanabaena papillaterminata (Kisselev)

Kukk

Rhabdoderma lineare Schmidle \& Lauterborn

\section{Chrysophyceae}

Mallomonas heterospina

\section{Euglenophyceae}

Euglena pisciformis Klebs

Euglena proxima P.A.Dangeard Phacus pleuronectes (O. F. Muller)

Dujardin 


\section{CONCLUSION}

The phytoplankton communities, and the biochemical content of these communities, can be considered ecosystem biomarkers at different sites in Wadi El-Rayan lakes. The biochemical composition of phytoplankton could be a valid integrator of surrounding environments in which phytoplankton grow and can be a good indicator of their nutritional value.

\section{REFERENCES}

Abd Ellah R.G. (2016) Bathymetric study of Wadi El-Rayan lakes, Egypt. Lakes, Reservoirs and Ponds, ORomanian Limnogeographical Association 10(2):110-125.

Abd El-Karim M.S. (2004) Ecological studies on periphytic algal communities in Wadi El-Rayian Lakes. Ph.D Thesis, Botany Department, Girls College, Ain-Shams University, Egypt.

AbdelHameed M.S., Hammouda O., Kobbia I., and Hassan S. (2007) Correlation between algal taxa and physico-chemical characters of the protected area of Wadi El-Rayan. Egypt Int J AgricBiol 9(1):1-10.

Abdel-Satar A.M., and Goher M.E. (2015) Heavy metals fractionation and risk assessment in surface sediments of Qarun and Wadi El- Rayan Lakes, Egypt. EnvironMonitAssess 187(6):1-12.

Ali M.H., Abdel-TawabA.A., and SolimanA.M. (2007) Monitoring of water quality and some pollutants of Man-Made Lake (Wadi El-Rayan first Lake, Egypt). Egypt J AquatBiol Fish 11(3):1235-1251.

Boëchat I.G., and Giani A.(2000). Factors affecting the biochemical composition of seston in an eutrophic reservoir (Pampulha reservoir, Belo Horizonte, MG). Rev Bras Biol 60(1):63-71.

Chabrol E., and Castellano A. (1961). SPV method for estimation of total serum lipid. J LabClin Med 57:300.

David J.H., and Hazel P. (1993). Analytical biochemistry. Handbook, 18th ed., $497 \mathrm{pp}$.

Doherty V.F.,OgunkuadeO.O., andKanifeU.C. (2010) Biomarkers of oxidative stress and heavy metal levels as indicators of environmental pollution in some selected fishes in Lagos, Nigeria. Am-Eurasian J Agric Environ Sci 7(3):359-365. 
Dubois M., Gilles K.A.,Hmilton J.K., Rebers P.A., and Smith F. (1956). Colorimetric method of determination of sugars and related substances. AnalChem 28(3):350-356.

Fawzy M.A., Abdel-WahabD.A., and Hifney A.F. (2017) Physiological and biochemical responses of the green alga Pachycladellachodatii (SAG 2087) to sodicity stress. J Basic ApplZool4(1):30-36.

Hannford L.T., and Britton M.E. (1952) The algae of Illinois, Chicago Press, Chicago, Illinois, U.S.A., 407 pp.

Hendey N.I. (1964). An introductory account of the smaller algae of British Coastal water. V. Bacillariophyceae, HMSO, London, 318 pp.

Jónasdóttir S. H. (2019). Fatty Acid Profiles and Production in Marine Phytoplankton. Mar. Drugs. 151; doi:10.3390/md17030151

Kofiod C.A. (1911). On Ceratium eugrammum and its related species. Zool. Anz. Leipzig Bd. xxx11 No.1.

Kofiod C.A., and Swez E.S. 1(921). The free living unarmoured dianoflagellates. Mem, of the Univ. of California.

Konsowa A.H., and Abd Ellah R.G. (2002)Physico-chemical characteristics and their effects on phytoplankton community in Wadi El-Rayian Lakes, Egypt. J EgyptAcadSoc Environ Develop 3(2):1-27.

Konsowa A.H., and Taha O.E. (2002). Physico-chemical characteristics and species composition of phytoplankton at the freshwater and estuary of Rosetta branch of the Nile (Egypt). J EgyptAcadSoc Environ Develop 3(1):85-105.

Konsowa A.H. (2007) Trophic status and phytoplankton community structure in Wadi El-Rayian lakes, western desert, Egypt. Egyptian J of Phycol 8(1):53-66.

KrammerK., and Lang-Bertalot H. (1991) Bacillariophyceae 3. Tell: Centrales, Fragilariaceae, Eunotiaceaesubwasserflora von. Mitteleuropa. Herausgegeben, Von. H. Ettl. J. Gerloff. H. Heynig D. Mollenhauer. Band $2 / 3$. Gustay Fischer Verlag. Jena, Stuttgart, $576 \mathrm{pp}$.

Lebour F.Z.S., and Marie V. (1930) The dinoflagellates of northern seas. Published by Marine Biological Association of The United Kingdom, 250 pp.

Mansour S.A., and Sidky M.M. (2003) Ecotoxicological studies. 6. The first comparative study between Lake Qarun and Wadi El-Rayan wetland (Egypt), with respect to contamination of their major components. J Food Chem 82(2):181-189. 
Mizuno T. (1990) Illustration of the Freshwater plankton of Japan. 9th printing, Hoikush publishing Co., LT, Japan, 353 pp.

Goher M.E.,Mahdy E.S.,Abdo M.H., Farida M.,Korium M.A., and Elsherif A.A. (2017) Water quality status and pollution indices of Wadi El-Rayan lakes, El-Fayoum, Egypt. Sustain Water ResourManag 5(2):387-400.

Müller-Navarra D.C., Brett M., and Liston A.M (2000) A highly unsaturated fatty acid predicts carbon transfer between primary producers and consumers. Nature 403:74-77.

Myklestad S., and Haug A. (1972) Production of carbohydrate by the marine diatom Chaetocerosaffinis var. Willei (Gran) Hustedt. Effect of the concentration of nutrient in the culturemedium. JExp MarBiolEccol 9:125136.

Paleczny D.,Allam K., andTalaat M. (2007) The state of Wadi El-Rayan protected area and valley of the whales world heritage site, an evaluation of management effectiveness. Egyptian-Italian Envi- ronmental Cooperation Programme, Nature Conservation Sector Capacity Building Project, Cario. Report.

Poonam T.,Tanushree B., and Sukalyan C. (2013) Water quality indicesimportant tools for water quality assessment, a review. Intern J AdvChem (IJAC) 1(1):15-29.

Prescott A.G.W. (1978) Temperature and manganese as determining factor in the presence of diatoms or blue green algal flora in stream.roc. NatAcad 64:472-478.

Saeed S.M., and Ibrahim M.I. (2008). Assessment of heavy metals pollution in water and sediments and their effect on OreochromisNiloticus in the northern delta lakes, Egypt. In: 8th international sympo- sium on tilapia in aquaculture.

Taha O.E., and Farghaly M.E. (1994) Ecological studies on Wadi El-Rayian Lakes. Distribution of phytoplankton and chlorophyll a. Vet Med J 42(3):139-149. 


\title{
التركيب والتحليل الحيوى الكيميائي للعوالق النباتية في بحيرات وادي الريان ،

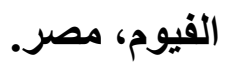

\author{
سعاد احمد علي سبع ، عبير محمد احمد محمود

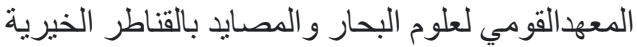 \\ الملخص العربي
}

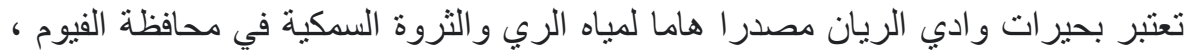

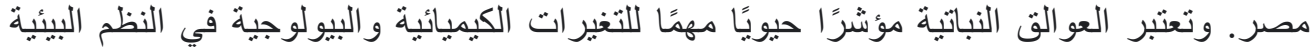

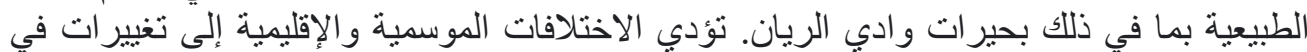

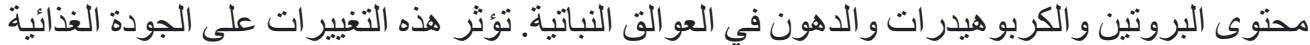

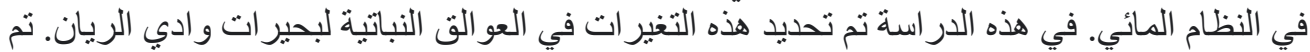

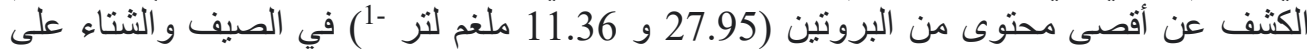
التو الي. وكان الحد الأقصى لمحتوى الكربو هيدر ات في الخريف و والثتاء (1.76 و 1.12 و 1.12 ملغم لتر -1 في في

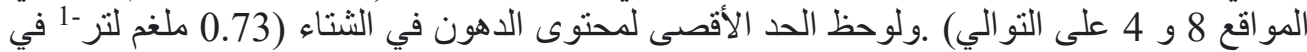

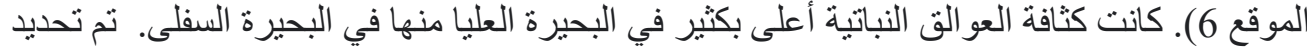

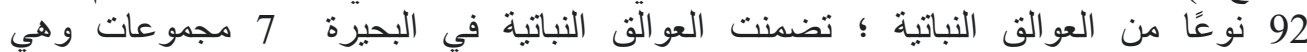
و Cryptophyceae , Bacillariophyceae , Cyanophyceae , Chlorophyceae Euglenophyceae g Chrysophyceae g Dinophyceae (Chlorophyceae)

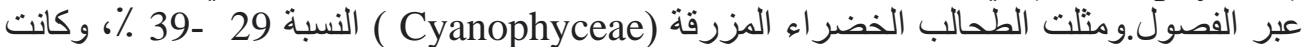

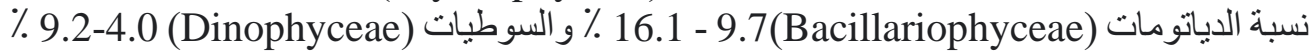

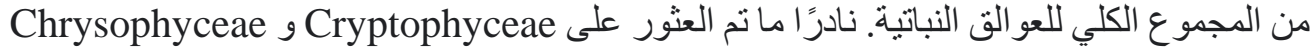

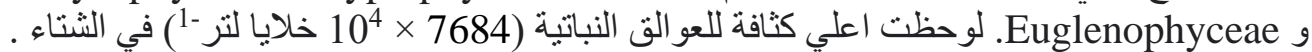

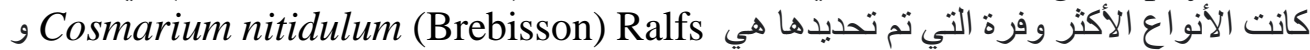
و Oocystis solitaria Wittrock و Dictyosphaerium pulchellum Wood Lyngbya limnetica, Gomphosphaeria compacta (Lammermann) Ström Cyclotella meneghiniana gicrocystis aeruginosa Kützing g Lemmermann Syndra ulna (Nitzsch) Ehr. و Kutz

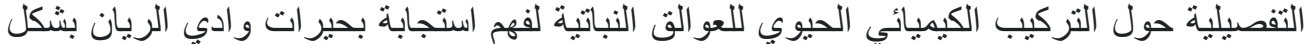
أفضل للتغير ات البيئية العديدة. الخلاصة:

يمكن اعتبار مجتمعات العو الق النباتية ، و المحتوى الكيميائي الحيوي لها، من المؤشرات الحيوية

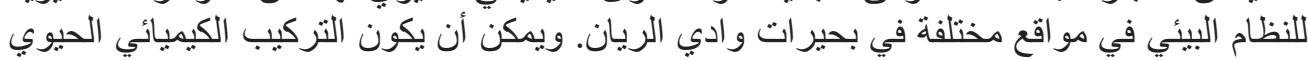

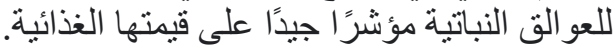

